九州大学学術情報リポジトリ

Kyushu University Institutional Repository

\title{
Density Analysis and Carbon Age Estimation of Taiwan Cypress Burl Wood Figure
}

HUANG, We i-Chih

Department of Wood Based Materials and Design, College of Agriculture, National Chiayi

University, Chiayi : Master

JANE, Ming-Chun

Department of Forestry and Natural Resources, College of Agriculture, National Chiayi University

FUJIM0T0, Noboru

九州大学大学院農学研究院環境農学部門

LIN, Han Chien

Laboratory of Environment Functional Materials, Department of Wood Based Materials and Design, College of Agriculture, National Chiayi University, Chiayi

https://doi.org/10.5109/4363554

出版情報: 九州大学大学院農学研究院紀要. 66 (1)，pp.69-76，2021-03-01. Faculty of Agriculture， Kyushu University

バージョン :

権利関係 : 


\title{
Density Analysis and Carbon Age Estimation of Taiwan Cypress Burl Wood Figure
}

\author{
Wei-Chih HUANG ${ }^{1}$, Ming-Chun JANE ${ }^{2}$, Noboru FUJIMOTO and Han Chien LIN ${ }^{3 *}$
}

\author{
Laboratory of Wood Material Technology, Division of Sustainable Bioresources Science, \\ Department of Agro-environmental Sciences, Faculty of Agriculture, \\ Kyushu University, Fukuoka 819-0395, Japan \\ (Received October 22, 2020 and accepted November 4, 2020)
}

\begin{abstract}
This study used Soft X-ray image analysis and radiocarbon dating (14C dating) to analyze the density and estimate carbon age (14C age) of Taiwan cypress burl wood figures (BWFs). The densities of waterripple, sliver-ripple, peanut-like, phoenix tail-like, nail-like, and thorn-like burl figures were 0.64, 0.68, $0.73,0.71,0.93$, and $0.86 \mathrm{~g} / \mathrm{cm}^{3}$, respectively, which were higher than both of Chamaecyparis formosensis $\left(0.50 \mathrm{~g} / \mathrm{cm}^{3}\right)$ and Chamaecyparis obtusa var. formosana $\left(0.54 \mathrm{~g} / \mathrm{cm}^{3}\right)$. Physical organizational changes, cellular morphology, orientation of wood, and the amount of chemical substance (inclusion) might be related to BWF density variations. Both sides of a bright band or adjacent surfaces had different densities due to tracheid pattern differences. The higher nail dot density was supposed to be related to the inclusion. The 14C ages of water-ripple, sliver-ripple, peanut-like, phoenix tail-like, nail-like, and thorn-like burl figures were about $382,180,480,342,173$, and $277 \mathrm{BP}$, respectively, meaning the precedence order of $14 \mathrm{C}$ ages of various BWFs might not be related to the complexity or density of BWF patterns. In addition to the time course, the formation of BWF patterns was related to the physical organizational or chemical substance changes, such as the cellular morphology, arrangement, or amount of inclusion of wood.
\end{abstract}

Key words: Taiwan Cypress Burl, Burl Wood Figure (BWF), Density, 14C age

\section{INTRODUCTION}

Burl (Wikipedia, 2020) forms have different burl wood figure (BWF) patterns due to variations in cellular morphology and arrangement (Huang et al., 2020), there may be significant differences in the density of the same section, and different BWF patterns may have different densities. As X-rays have penetrability, and there is intensity attenuation after penetration, it is one of nondestructive testing techniques. The wavelength of a Soft $\mathrm{X}$-ray is $0.3-10.0 \mathrm{~nm}$, which is suitable for wood inspection due to its weaker penetrating power (Kirz and Jacobsen, 1995). Taking fall wood as an example, the degree of attenuation (material absorption) of Soft Xray intensity is higher, and the color inclines to white, while spring wood is on the contrary (Lin et al., 2005). Therefore, the BWF density variations of different patterns of a burl are analyzed using the Soft X-ray shooting technique, which can be corresponded to the BWF patterns and cellular arrangements in prior reports (Huang et al., 2020). Gülsoy et al. (2005) indicate that the burl density is related to the amount of resinous substance accumulated in wood rays.

The $14 \mathrm{C}$ dating method can be used to estimate the age of cultural relics or as an age reference for paleoen-

\footnotetext{
Master, Department of Wood Based Materials and Design, College of Agriculture, National Chiayi University, Chiayi, Taiwan, ROC

2 Department of Forestry and Natural Resources, College of Agriculture, National Chiayi University, Chiayi, Taiwan, ROC

3 Laboratory of Environment Functional Materials, Department of Wood Based Materials and Design, College of Agriculture, National Chiayi University, Chiayi, Taiwan, ROC

* Corresponding author (E-mail: alexhlin@mail.ncyu.edu.tw)
}

vironment and paleoclimate studies (Hajdas, 2009; Kuzmin, 2009; Wood, 2015). As carbon dioxide with 14C enters the food chain through the photosynthesis of plants, animals and plants have a certain proportion of carbon isotopes (e.g. 12C, 13C and 14C), which are no longer exchanged with the outside as the plants die. However, in order to estimate the time of death of animals and plants, as unstable 14C decays continuously, the $14 \mathrm{C}$ age can be estimated by determining the $14 \mathrm{C}$ concentration remaining in the organic remains and calculating the assumed half-life (Баранов, 2004; Wood, 2015).

Taiwan cypress burl has multiple appearances and internal morphology, the formation of a wood figure is similar to that of a BWF (Huang et al., 2020), and the Taiwan cypress BWF pattern and cellular morphology might be described by the density analysis of Soft X-ray. The study investigated the densities of different BWF patterns form the Taiwan cypress burl, and used 14C dating to estimate $14 \mathrm{C}$ age, which was intended to provide a reference for the cognition of Taiwan cypress BWFs.

\section{MATERIALS AND METHOD}

\section{Test materials}

Taiwan cypress burl processing remainder

The specimens for density analysis and carbon age (14C age) estimation were taken from a burl artwork processing plant, the patterns of BWF were compared by the previous paper (Huang et al., 2020), and before testing the BWF patterns were also confirmed by senior collectors in Taiwan. 


\section{Experimental methods}

$B W F$ density analysis

The Soft X-ray photographic box (MODEL 43855A OPTION A02, Hewlett-Packard Faxitron, America) was used with negative film (INDUSTREX MX125 Film, Carestream Health, America) for shooting, and correction wedges (WALESCH Electronic 06.07.01 ES, Walesch Electronic, Switzerland) in different thicknesses and gradients were used as standards. The shooting conditions included tube voltage $14 \mathrm{kv}$, tube current $0.375 \mathrm{~mA}$, and shooting time of $7 \mathrm{~min}$. The negative film (gray scale image) was scanned by an image scanner (Epson Expression 10000 XL, Seiko Epson, Japan), wherein the measuring axis was planned, and measuring axis density analysis is performed by image analysis software (Image-Pro Plus 6.0.0.260 for Windows, Media Cybernetics, America) and regression analysis software (SigmaPlot for Windows 10.0, Systat Software, America) (Kirz and Jacobsen, 1995; Lin et al., 2005).

\section{BWF $14 C$ age estimation}

The $14 \mathrm{C}$ ages (before present, BP; radiocarbon years before 1950) of various BWFs and error values were determined by Accelerator Mass Spectrometry (Accelerator Mass Spectrometry; High Voltage Engineering Europa B.V., HVEE, Netherlands).

\section{RESULTS AND DISCUSSION}

\section{BWF density analysis}

\section{Water-ripple figure}

The macroscopic bright band of the water-ripple figure is straight lines, which are arranged slightly parallel with each other and regular, like a wavy figure, and the cells are longitudinal tracheid pattern (including sliver, discontinuous, turning zone and sliver inclusion) with part of wood ray pattern (such as: crossover region) in the microscopic view. The tracheid patterns on both sides of the bright band are slightly different from each other, and the bright band has different reflected degrees from light due to different tracheid patterns, which are relatively apparent in vision (Huang et al., 2020). Table 1 showed the general view (left) and gray scale image (right) of the water-ripple figure specimen.
The densities on both sides of the bright band were analyzed with different measuring axes. The maximum density of $\mathrm{A}_{0} \mathrm{~A}_{1}$ was $0.67 \mathrm{~g} / \mathrm{cm}^{3}$, the minimum density was $0.47 \mathrm{~g} / \mathrm{cm}^{3}$, and the maximum and minimum densities of $\mathrm{B}_{0} \mathrm{~B}_{1}$ were about 0.70 and $0.47 \mathrm{~g} / \mathrm{cm}^{3}$, respectively, those of $\mathrm{C}_{0} \mathrm{C}_{1}$ were 0.83 and $0.46 \mathrm{~g} / \mathrm{cm}^{3}$, those of $\mathrm{D}_{0} \mathrm{D}_{1}$ were 0.94 and $0.59 \mathrm{~g} / \mathrm{cm}^{3}$, those of $\mathrm{E}_{0} \mathrm{E}_{1}$ were 0.88 and $0.58 \mathrm{~g} / \mathrm{cm}^{3}$, and the densities of $\mathrm{A}_{0} \mathrm{~A}_{1}, \mathrm{~B}_{0} \mathrm{~B}_{1}, \mathrm{C}_{0} \mathrm{C}_{1}, \mathrm{D}_{0} \mathrm{D}_{1}$, and $\mathrm{E}_{0} \mathrm{E}_{1}$ were $0.54,0.57,0.61,0.75$, and $0.71 \mathrm{~g} / \mathrm{cm}^{3}$, respectively. The density of wood is generally related to the thickness of the cell wall and cell cavity diameter and positively correlated with cell wall thickness, and negatively correlated with the length, width, cavity diameter, and the amount of vessel (Roque and Tomazello Filho, 2007). For example: fall wood has thick cell walls, small cavity, and denser arrangement. It has higher density than spring wood. The differences in cellular morphology might influence the density of wood, and the straight line-like bright band of the water-ripple figure had different reflected degrees of light due to the morphological difference between the sides of tracheid pattern.

\section{Sliver-ripple figure}

The sliver-ripple figure ( $\mathrm{Q}$ filament) is curvilinear or electric wave-like, two adjacent bright bands intersect each other and surround the lusterless surface, and several blocks are formed between the bright band and lusterless (adjacent) surface, which is similar to the pattern of a mottled figure. In microscopic view, the tracheid patterns are sliver, discontinuous, and pore; the accumulated inclusion was sliver and punctate inclusion; and the wood ray pattern presents crossover region (Huang et al., 2020). Table 2 showed the general view (left) and gray scale image (right) of the sliver-ripple figure specimen.

The density of sliver-ripple figure was observed in the general view of the specimen that two curvilinear bright bands intersected each other, and this trend was somewhat normal to spring and fall woods. The surface around the bright band was somewhat lusterless. The density of measuring axes $\mathrm{A}_{0} \mathrm{~A}_{1}$ and $\mathrm{B}_{0} \mathrm{~B}_{1}$ of the lusterless surface was all $0.72 \mathrm{~g} / \mathrm{cm}^{3}$, the $\mathrm{C}_{0} \mathrm{C}_{1}$ of the bright band was lower $0.61 \mathrm{~g} / \mathrm{cm}^{3}$, the maximum densities were about $1.02,0.96$, and $0.94 \mathrm{~g} / \mathrm{cm}^{3}$, and the minimum values were

Table 1. Soft X-ray density analysis of water-ripple figure of Chamaecyparis formosensis specimen

\begin{tabular}{|c|c|c|c|}
\hline Axes & Density $\left(\mathrm{g} / \mathrm{cm}^{3}\right)$ & General view & Gray scale image ${ }^{1)}$ \\
\hline $\mathrm{A}_{0} \mathrm{~A}_{1}$ & $0.54(0.05)^{\mathrm{a} 2)}$ & & \\
\hline $\mathrm{B}_{0} \mathrm{~B}_{1}$ & $0.57(0.05)^{b}$ & & \\
\hline $\mathrm{C}_{0} \mathrm{C}_{1}$ & $0.61(0.06)^{c}$ & & \\
\hline $\mathrm{D}_{0} \mathrm{D}_{1}$ & $0.75(0.08)^{\mathrm{e}}$ & & \\
\hline $\mathrm{E}_{0} \mathrm{E}_{1}$ & $0.71(0.07)^{\mathrm{d}}$ & & +1 \\
\hline
\end{tabular}

1) Film image of Soft X-ray density analysis

2) Mean (standard deviation) by Duncan's multiple range tests at 5\% significant level 
Table 2. Soft X-ray density analysis of sliver-ripple figure of Chamaecyparis formosensis specimen

\begin{tabular}{|c|c|c|c|}
\hline Axes & Density $\left(\mathrm{g} / \mathrm{cm}^{3}\right)$ & General view & Gray scale image $^{1)}$ \\
\hline $\mathrm{A}_{0} \mathrm{~A}_{1}$ & $0.72(0.11)^{\mathrm{b} 2)}$ & & \\
\hline $\mathrm{B}_{0} \mathrm{~B}_{1}$ & $0.72(0.09)^{\mathrm{b}}$ & & \\
\hline $\mathrm{C}_{0} \mathrm{C}_{1}$ & $0.61(0.11)^{\mathrm{a}}$ & & \\
\hline
\end{tabular}

${ }^{1)}$ and ${ }^{2)}$ See Table 1

$0.48,0.55$, and $0.42 \mathrm{~g} / \mathrm{cm}^{3}$, respectively, meaning there were different densities between bright band and lusterless surface.

\section{Peanut-like figure}

The peanut-like figure is characterized by the mushroom-swirled shape with a concentric circle, which is similar to the blister figure, as the surface has dark colored lines and is arranged outwards in the form of concentric circles to form several irregular dark colored circles (Huang et al., 2020). Table 3 showed the general view (left) and gray scale image (right) of the peanutlike figure specimen.

The maximum and minimum densities of the $A_{0} A_{1}$ measuring axes were 0.70 and $0.52 \mathrm{~g} / \mathrm{cm}^{3}$, respectively, those of $\mathrm{B}_{0} \mathrm{~B}_{1}$ were 0.91 and $0.65 \mathrm{~g} / \mathrm{cm}^{3}$, those of $\mathrm{C}_{0} \mathrm{C}_{1}$ were 0.97 and $0.63 \mathrm{~g} / \mathrm{cm}^{3}$, and the maximum and minimum densities of $\mathrm{B}_{0} \mathrm{~B}_{1}$ were close to those of $\mathrm{C}_{0} \mathrm{C}_{1}$, which were higher than those of $\mathrm{A}_{0} \mathrm{~A}_{1}$. The $\mathrm{A}_{0} \mathrm{~A}_{1}$ analyzed the density of the grey black region in the gray scale image, which corresponded to the general view of the specimen, and was the periphery of the concentric circles pattern.
$\mathrm{B}_{0} \mathrm{~B}_{1}$ and $\mathrm{C}_{0} \mathrm{C}_{1}$ were the effect of the concentric circles pattern center amount on density. The densities of $\mathrm{A}_{0} \mathrm{~A}_{1}$, $\mathrm{B}_{0} \mathrm{~B}_{1}$, and $\mathrm{C}_{0} \mathrm{C}_{1}$ were $0.56,0.76$, and $0.87 \mathrm{~g} / \mathrm{cm}^{3}$, respectively, meaning in a range, and the concentric circles pattern center amount was related to density. The conifer compression wood has higher specific gravity when the pore of wood cells was compressed. The density is increased because the cavity volume of cells is reduced (Westing, 1965). In the nonuniform growing process of BWF, as there might be compression in the portion of growth range, the close arrangement of the tracheid at the center of the concentric circles pattern might be related to compression.

\section{Phoenix tail-like figure}

The phoenix tail-like figure which has both swirl and feather patterns for different sections is similar to a crotch figure. The tracheid pattern of the phoenix taillike figure has the tracheid of longitudinal and cross sections, and such patterns have different light reflected degrees. The phoenix tail-like figure has the tracheid patterns of sliver, discontinuous, pore, sliver inclusion

Table 3. Soft X-ray density analysis of peanut-liked figure of Chamaecyparis obtusa var. formosana specimen

\begin{tabular}{lccc}
\hline Axes & Density $\left(\mathrm{g} / \mathrm{cm}^{3}\right)$ & General view & Gray scale image $^{1)}$ \\
\hline $\mathrm{A}_{0} \mathrm{~A}_{1}$ & $0.56(0.03)^{\mathrm{a} 2)}$ & & \\
$\mathrm{B}_{0} \mathrm{~B}_{1}$ & $0.76(0.07)^{\mathrm{b}}$ & $\mathrm{A}_{0}$ & \\
$\mathrm{C}_{0} \mathrm{C}_{1}$ & $0.87(0.09)^{\mathrm{c}}$ & $\mathrm{B}_{1}$ & $\mathrm{C}_{1}$ \\
\hline
\end{tabular}

${ }^{1)}$ and ${ }^{2)}$ See Table 1

Table 4. Soft X-ray density analysis of phoenix tail-liked figure of Chamaecyparis formosensis specimen

\begin{tabular}{|c|c|c|c|}
\hline Axes & Density $\left(\mathrm{g} / \mathrm{cm}^{3}\right)$ & General view & Gray scale image $^{1)}$ \\
\hline $\mathrm{A}_{0} \mathrm{~A}_{1}$ & $0.49(0.11)^{\mathrm{a} 22)}$ & & \\
\hline $\mathrm{B}_{0} \mathrm{~B}_{1}$ & $0.61(0.12)^{\mathrm{c}}$ & & \\
\hline $\mathrm{C}_{0} \mathrm{C}_{1}$ & $0.55(0.13)^{b}$ & & \\
\hline $\mathrm{D}_{0} \mathrm{D}_{1}$ & $0.71(0.06)^{\mathrm{e}}$ & & \\
\hline $\mathrm{E}_{0} \mathrm{E}_{1}$ & $0.63(0.07)^{\mathrm{d}}$ & & \\
\hline $\mathrm{F}_{0} \mathrm{~F}_{1}$ & $0.84(0.08)^{\mathrm{f}}$ & & \\
\hline $\mathrm{G}_{0} \mathrm{G}_{1}$ & $1.14(0.06)^{g}$ & & \\
\hline
\end{tabular}

1) and 2 See Table 1 
and punctate inclusion with the part of wood ray pattern, such as crossover region. The feather bright bands are usually divided by a lusterless surface between them. There is a gradient effect due to different glosses (Huang et al., 2020). The general view (left) of the phoenix tail-like figure specimen had feather bright bands and a lusterless surface between them, the pattern was complex, and it seemed there was a center position (swirl), meaning where the bright band spreads out like a feather (Table 4).

While the surface that measuring axis $\mathrm{A}_{0} \mathrm{~A}_{1}$ passes through was relatively lusterless, the surface that $\mathrm{F}_{0} \mathrm{~F}_{1}$ passes through had relatively dense arrangement of annual rings. The color of the center position of the gray scale image (right) inclined to ash grey, which was obviously different from the peripheral color. The lusterless surfaces were $\mathrm{B}_{0} \mathrm{~B}_{1}$ and $\mathrm{D}_{0} \mathrm{D}_{1}$, and the bright bands were $\mathrm{C}_{0} \mathrm{C}_{1}$ and $\mathrm{E}_{0} \mathrm{E}_{1}$. The maximum densities of $\mathrm{A}_{0} \mathrm{~A}_{1}, \mathrm{~B}_{0} \mathrm{~B}_{1}$, $\mathrm{C}_{0} \mathrm{C}_{1}, \mathrm{D}_{0} \mathrm{D}_{1}, \mathrm{E}_{0} \mathrm{E}_{1}, \mathrm{~F}_{0} \mathrm{~F}_{1}$, and $\mathrm{G}_{0} \mathrm{G}_{1}$ were $0.94,0.88,0.86$, $0.86,0.80,0.98$, and $1.24 \mathrm{~g} / \mathrm{cm}^{3}$, respectively, the minimum values of those were $0.31,0.41,0.36,0.56,0.47$, 0.64 , and $0.98 \mathrm{~g} / \mathrm{cm}^{3}$, and the densities of all measuring axes were $0.49,0.61,0.55,0.71,0.63,0.84$, and $1.14 \mathrm{~g} /$ $\mathrm{cm}^{3}$ (Table 4), meaning the complexity of the phoenix tail-like figure pattern was related to density. In general, tree rings do not grow in positive concentric circles; taking reaction wood as an example, the annual rings grow eccentrically as the tree tilts, and the annual rings on the compressed side become narrow and denser (Westing, 1965). The densities of the bright band and lusterless surface; therefore, might be related to morphological differences, and be different due to growth difference.

\section{Nail-like figure}

The nail-liked figure has various randomly distrib- uted irregular dark colored dots of different sizes, which are known as "nail dots", similar to a burl figure, and related to the bud points of the adventitious buds or dormant buds. The multiple tracheid patterns, e.g. intersection, hook, and/or swirl patterns with the inclusion patterns of sliver and punctate inclusion concentration site and moniliform (Huang et al., 2020). Table 5 showed the general view (left) of nail-like figure specimen, where it was observed that there were randomly distributed nail dots of different sizes, as well as some fissures or hole-patterns.

The color of the nail dots in the gray scale image (right) inclines to grey color, as compared with the peripheral surface, and dark black lines or holes could be observed in some nail dots, which were the fissures or holes in the general view of the specimen. The densities of measuring axes $\mathrm{A}_{0} \mathrm{~A}_{1}, \mathrm{~B}_{0} \mathrm{~B}_{1}$, and $\mathrm{C}_{0} \mathrm{C}_{1}$ were $0.75,1.01$, and $1.02 \mathrm{~g} / \mathrm{cm}^{3}$, respectively, while $\mathrm{A}_{0} \mathrm{~A}_{1}$, which had not passed through the nail dots, had the minimum density, $\mathrm{B}_{0} \mathrm{~B}_{1}$ and $\mathrm{C}_{0} \mathrm{C}_{1}$, which passed through nail dots, had higher density, and their maximum densities were 0.93, 1.21 , and $1.20 \mathrm{~g} / \mathrm{cm}^{3}$, respectively, and the minimum values are $0.57,0.47$ and $0.74 \mathrm{~g} / \mathrm{cm}^{3}$. In the microscopic view of this pattern, the density of the nail dots was related to the large amount of accumulated inclusion (Huang et al., 2020). In addition, a burl contains a lot of resinous substance and has higher density than general wood (Gülsoy et al., 2005).

\section{Thorn-like figure}

The surface of the thorn-like figure has the bright band and nail dot patterns simultaneously, which is similar to a burl figure, the nail dots are clustered in a range and the bright band vignettes out from a nail dot or the center of the cluster (Huang et al., 2020). Table 6

Table 5. Soft X-ray density analysis of nail-liked figure of Chamaecyparis obtusa var. formosana specimen

\begin{tabular}{|c|c|c|c|}
\hline Axes & Density $\left(\mathrm{g} / \mathrm{cm}^{3}\right)$ & General view & Gray scale image $^{11}$ \\
\hline $\mathrm{A}_{0} \mathrm{~A}_{1}$ & $0.75(0.07)^{\mathrm{a} 2)}$ & & \\
\hline $\mathrm{B}_{0} \mathrm{~B}_{1}$ & $1.01(0.13)^{\mathrm{b}}$ & & \\
\hline $\mathrm{D}_{0} \mathrm{D}_{1}$ & $1.02(0.13)^{\mathrm{c}}$ & & \\
\hline
\end{tabular}

${ }^{1)}$ and ${ }^{2)}$ See Table 1

Table 6. Soft X-ray density analysis of thorn-liked figure of Chamaecyparis obtusa var. formosana specimen

\begin{tabular}{lccc}
\hline Axes & Density $\left(\mathrm{g} / \mathrm{cm}^{3}\right)$ & General view & Gray scale image $^{1)}$ \\
\hline $\mathrm{A}_{0} \mathrm{~A}_{1}$ & $0.95(0.06)^{\mathrm{c} 2)}$ & $\mathrm{C}_{0}$ & \\
$\mathrm{~B}_{0} \mathrm{~B}_{1}$ & $0.85(0.06)^{\mathrm{b}}$ & $\mathrm{B}_{1}$ & \\
$\mathrm{D}_{0} \mathrm{D}_{1}$ & $0.79(0.05)^{\mathrm{a}}$ & $\mathrm{A}_{0}$ & $\mathrm{~A}_{0}$ \\
\hline
\end{tabular}

${ }^{1)}$ and ${ }^{2)}$ See Table 1 
showed the general view (left) of the thorn-liked figure specimen, which showed several dark colored dot patterns, i.e. "nail dots", clustering in a place. Some curvilinear bright bands vignette out from the center or periphery of the nail dots, and this trend was somewhat normal to spring and fall woods.

The maximum densities of measuring axes $\mathrm{A}_{0} \mathrm{~A}_{1}$, $\mathrm{B}_{0} \mathrm{~B}_{1}$, and $\mathrm{C}_{0} \mathrm{C}_{1}$ were $1.04,0.98$, and $0.91 \mathrm{~g} / \mathrm{cm}^{3}$, respectively, while the minimum densities of those were 0.80 , 0.64 , and $0.69 \mathrm{~g} / \mathrm{cm}^{3}$. The densities of $\mathrm{A}_{0} \mathrm{~A}_{1}, \mathrm{~B}_{0} \mathrm{~B}_{1}$, and $\mathrm{C}_{0} \mathrm{C}_{1}$ were $0.95,0.85$, and $0.79 \mathrm{~g} / \mathrm{cm}^{3}$, respectively, wherein $\mathrm{A}_{0} \mathrm{~A}_{1}$ had the highest density through the range of nail dots. According to the gray scale image (right), the color of the region of the nail dots inclines to ash grey, and the density is higher, which is related to the inclusion (Eom and Chung, 1994; Crane et al., 1995; Gülsoy et al., 2005; Kilic et al., 2012).

\section{Comparison of BWF densities}

The densities of various BWF patterns were analyzed by measuring axes, such as the bright band and dot pattern (nail dot), the densities of various BWF were listed in Table 1 to Table 6, and the density variation between different BWF was comprehensively described, as shown in Table 7. The average densities of the waterripple, sliver-ripple, peanut-like, phoenix tail-like, naillike, and thorn-like burl figures were about 0.64, 0.68, $0.73,0.71,0.93$, and $0.86 \mathrm{~g} / \mathrm{cm}^{3}$, respectively. In terms of the water-ripple, sliver-ripple, phoenix tail-like, and thorn-like burl figures, the surfaces on both sides of the bright band or adjacent surfaces had different densities; e.g. the left side $\left(A_{0} A_{1}\right)$ and right side $\left(B_{0} B_{1}\right)$ of the bright band of the water-ripple figure (Table 1 ), or the lusterless surface $\left(\mathrm{B}_{0} \mathrm{~B}_{1}\right)$ and bright band $\left(\mathrm{C}_{0} \mathrm{C}_{1}\right)$ of the sliverripple figure (Table 2 ), or the peanut-like figure (Table 3 ), which had higher density in the center $\left(\mathrm{B}_{0} \mathrm{~B}_{1}\right)$ of the concentric circles pattern. In addition, the nail dots of the nail-like and thorn-like burl figures had higher density. Taking the nail-like figure as an example, such as $\mathrm{B}_{0} \mathrm{~B}_{1}$ was shown in Table 5 . The density variation between the bright band and peripheral surface (e.g., cellular morphology) of the water-ripple, sliver-ripple, phoenix tail-like, and thorn-like burl figures can be resulted from different tracheid patterns (Huang et al., 2020).

The water-ripple, sliver-ripple, peanut-like, and phoenix tail-like figures had similar densities, the thorn- like figure had the second highest density among the six BWFs, and the nail-like figure had the highest density. The densities could be classified by water-ripple, sliverripple, peanut-like, phoenix tail-like, nail-like, and thorn-like figures. After morphologic observation and wood figure comparison, Huang et al. (2020) indicate that the BWF patterns are divided into bright band, naillike, and thorn-like types. Different bright band patterns were able to be observed on the surfaces of waterripple, sliver-ripple, peanut-like, and phoenix tail-like figures, such as straight-line, curvilinear, or feather patterns, which were resulted as BWFs pattern (Table 7). The nail-like and thorn-like BWFs had nail dots, while the thorn-like figure had both nail dot and bright band patterns; therefore, the density of the bright band type BWF was related to the physical organizational changes of the tracheid pattern and arrangement. While the concentric circles pattern on the surface of peanut-like figure was resulted from the inclusion, its density was also related to the tracheid arrangement. In other words, the density variation of the nail-like burl figure depended on the amount of inclusion, and of thorn-like figure had both nail dots and bright bands.

\section{C age estimation of Taiwan cypress BWFs}

The BWF dating specimens and $14 \mathrm{C}$ dating results are shown in Table 8. The estimated 14C age is represented by BP, which is estimated ahead of 1950 as the 0th year (0 BP), as a larger BP value represents an earlier age to 1950 (Баранов, 2004; Wood, 2015). The estimated $14 \mathrm{C}$ ages of different pattern of the water-ripple, sliver-ripple, peanut-like, phoenix tail-like, nail-like, and thorn-like burl figures were about 382, 180, 480, 342,173 , and $277 \mathrm{BP}$, respectively.

According to the patterns in macroscopic view (Huang et al., 2020), the water-ripple and sliver-ripple figure patterns of the bright band type BWF are relatively specimen; whereas the peanut-like and phoenix tail-like figure patterns are relatively complex. The bright band of the latter two spread out from the center position, especially the phoenix tail-like figure with its multiple bright band patterns. The interfingering of a feather bright band and lusterless surface often result in a gradient. According to the above density analysis (Table 7), the nail-like and thorn-like burl figures had higher density than the bright band type, which was not induced by specimen physical cell tissue variation,

Table 7. Average density of burl wood figure specimens by using Soft X-ray analysis

\begin{tabular}{lcl}
\hline Pattern & $\begin{array}{c}\text { Average density } \\
\left(\mathrm{g} / \mathrm{cm}^{3}\right)\end{array}$ & \multicolumn{1}{c}{ BWF pattern (Huang et al., 2020) } \\
\hline Water-ripple figure & $0.64(0.09)^{\mathrm{a}}$ & Straight-line bright band type \\
Sliver-ripple figure & $0.68(0.06)^{\mathrm{b}}$ & Curvilinear bright band type \\
Peanut-liked figure & $0.73(0.16)^{\mathrm{d}}$ & Curvilinear with concentric circle bright band type \\
Phoenix tail-liked figure & $0.71(0.22)^{\mathrm{c}}$ & Feather bright band type \\
Nail-liked figure & $0.93(0.16)^{\mathrm{f}}$ & Nail dots nail-like type \\
Thorn-liked figure & $0.86(0.08)^{\mathrm{e}}$ & Flash light and nail dot thorn-like type \\
\hline
\end{tabular}


Table 8. ${ }^{14} \mathrm{C}$ age dating of burl wood figure specimens by using Accelerator Mass Spectrometry

\begin{tabular}{lc}
\hline Pattern & $14 \mathrm{C}$ age $\left(\mathrm{BP}^{1)}\right)$ \\
\hline Water-ripple figure & $382 \pm 31$ \\
Sliver-ripple figure & $180 \pm 22$ \\
Peanut-liked figure & $480 \pm 21$ \\
Phoenix tail-liked figure & $342 \pm 24$ \\
Nail-liked figure & $173 \pm 25$ \\
Thorn-liked figure & $277 \pm 20$
\end{tabular}

${ }^{1)}$ Radiocarbon years before 1950 ; that is, 1950 as the 0 th year (0 BP)

meaning the chemical substance variation with the inclusion might influence density.

The 14C age of various BWFs was only 241-450 years up to this year (2020), and far from the Taiwan cypress, which appropriated to be a thousand years old. However, because $14 \mathrm{C}$ dating belongs to the concept of organic remains, the concentration differences of carbon isotopes in the organisms only start from the time of death (Баранов, 2004). Moreover, the distance of wood cells to the cambium has different precedence orders, and there are differences between living cells and dead cells. Moreover, sapwood and heartwood have different $14 \mathrm{C}$ ages, and the dead wood cells have different $14 \mathrm{C}$ ages after the annual change from sapwood to heartwood. There are errors in the $14 \mathrm{C}$ age on the specimen site, which is known as the old wood effect (Bowman, 1990).

As the specimen are Taiwan cypress burl processing remainders, it is difficult to master the true age data of the original tree or burl, meaning the measured value only represents the $14 \mathrm{C}$ age of the specimen (the position of the burl), and the result only shows that the specimens has different $14 \mathrm{C}$ ages. The starting time of a burl could not be explored from the specimens or the relationship between the tree and the burl. The time of death; therefore, was determined based on $14 \mathrm{C}$ age. The predecessors indicate that the burl variation starts from periderm (Kelly and Black, 1949) or near pith (Eom and Chung, 1994), meaning the burl can form at the beginning of tree growth, and it might be induced by the influence of acquired growth variation. In terms of the latter one, the burl might not be formed until after years of arboreal growth so that the tree age was essentially different from the burl age.

In addition, there are numerous causes for the formation of wood figures or burls, including congenital growth condition, growth rate and size of trees, postnatal climate, soil, geographic location, height above sea level, latitude, and biological and non-biological effects, such as the wounds caused by insects, animals, or out- side disasters, cellular morphology, arrangement influenced by ambient temperature and humidity changes, natural disasters, invasive infection of pathogens, variation of tree genes, a lack of phytohormones, or other unknown effects (Black, 1945; Kelly and Black, 1949; Littau and Black, 1952a and 1952b; White and Millington, 1954a and 1954b; Ahuja, 1962; de Torok, 1968; Beals and Davis, 1977; Eklund and Säll, 2000; Dodueva et al., 2007; Schweingruber, 2007; Lukmandaru, 2015). White and Millington (1954a) mentioned that the Picea glauca burl grows in coastal regions with salt mist. Eklund and Säll (2000) mention that wind can influence the crown orientation of red pine (Pinus resinosa) and Norway spruce (Picea abies). As Taiwan is surrounded by seas, and there are monsoon and typhoon seasons every year, the geographic environment is similar to the burl habitat proposed by predecessors, and this might be one of the reasons for the rich and changeful patterns of Taiwan cypress burl.

The above causes can be attributed to wood cell variations, and wood figure formations, burl formations, and tree wounds are varied. According to morphologic observation (Huang et al., 2020) and density analysis in this study, the BWF pattern difference can be reflected in BWF density. According to some of studies, the factors influencing the density of wood are related to climate, monthly mean temperature, rainfall, planting density, and soil moisture (Bergès et al., 2008; Filipescu et al., 2013), and such factors can influence the density of wood, cell wall thickness, cell length, width, and cavity diameter (Roque and TomazelloFilho, 2007), meaning such factors are related to the physical organizational changes of wood cells. The bright band type of BWF is caused by cellular morphology and arrangement changes. It can be inferred that the bright band type is relatively related to environmental climate factors. In addition, predecessors mention that resin is the physiological or pathological secretion of plants (Gülsoy et al., 2005; Kilic et al., 2012), meaning chemical substances as inclusions are related to tree injuries, and it can be 
inferred that biological factors or environmental disasters have greater effect on the nail-like burl figure than environmental change. Moreover, it is impossible that the trees are influenced only by a few variable factors. The thorn-like burl figure might be resulted from multiple factors, and the bud points occurring after the tree is injured can be derived from the order, bud growth, and compressed peripheral cells, and also the cellular morphology arrangement can change, and such environmental changes influence the BWF pattern.

To sum up, many factors induce variations in woody textures, forming wood or wood figures. Whatever the reason, such variations take time and the longer the time, the greater the effect, meaning that time is of certain importance to the formation of BWF. However, as there are many complex and changeful causes for the formation of BWFs, taking the general views of pattern, density, and 14C age, it is only confirmed that the complexity of BWF patterns is induced by physical organizational and chemical substance changes of wood cells, and such changes vary with time.

\section{CONCLUSION}

The density of the bright band type burl figure was $0.64-0.73 \mathrm{~g} / \mathrm{cm}^{3}$, the nail-like burl figure had the highest density of $0.93 \mathrm{~g} / \mathrm{cm}^{3}$, and the thorn-like burl figure had the second highest density of $0.86 \mathrm{~g} / \mathrm{cm}^{3}$. According to microscopic pattern comparison, the different densities on both sides of the bright band or between the adjacent surfaces of water-ripple, sliver-ripple, phoenix tail-like, and thorn-like burl figures were resulted from different tracheid patterns. The center of the concentric circles pattern of the peanut-like figure had higher density, which was caused by the close arrangement of various tracheids. In addition, the higher density of nail dots on the nail-like and thorn-like burl figures might be related to the inclusion. The $14 \mathrm{C}$ ages of different pattern of water-ripple, sliver-ripple, peanut-like, phoenix taillike, nail-like, and thorn-like burl figures were about $382,180,480,342,173$, and 277 BP, respectively. The causes for the formation of bBWFs were complex, including biological and non-biological effects, and each effect takes time. The complexity of BWF patterns were directly related to physical organizational and chemical substance changes, such as the cellular morphology, arrangement of wood, and the amount of inclusion. While time was correlated with the formation of BWFs to some extent, the time length was indirectly related to BWF patterns.

\section{AUTHOR CONTRIBUTION}

Wei-Chih HuANG performed the experiments and analyzed the data. Ming-Chun JANE assisted the experiments and participated in the design of the study. Noboru Fusimoto supervised the works. Han Chien LiN designed this study and wrote the paper. The authors assisted in editing of the manuscript and approved the final version.

\section{ACKNOWLEDGEMENTS}

The authors offer our sincere appreciation to the Industry-University Cooperation Project "Study on Microstructure and Book Compilation of Taiwan Cypress Burl Wood Figures" for financial support. We offer our sincere appreciation to Mr. Lo, Wu for helping the experimental materials.

\section{REFERENCES}

Ahuja, M. R. 1962 A cytogenetic study of heritable tumors in Nicotiana species hybrids. Genetics, 47(7): 865-880

Beals, H. O. and T. C. Davis 1977 Figure in wood: an illustrated review. Agricultural Experiment Station. Auburn University, America. pp. 1-79

Black, L. M. 1945 A virus tumor disease of plants. American Journal of Botany, 32(7): 408-415

Bergès, L., G. Nepveu and A. Franc 2008 Effects of ecological factors on radial growth and wood density components of sessile oak (Quercus petraea Liebl.) in Northern France. Forest Ecology and Management, 255(3): 567-579

Bowman, S 1990 Radiocarbon dating (Vol. 1). University of California Press, America. pp. 1-64

Баранов, В. Ю. 2004 Isotopes: properties, preparation and application. Tsinghua University Press, Beijing. pp. 1-1000

Crane, P. E., P. V. Blenis and Y. Hiratsuka 1995 Black stem galls on aspen: anatomy and histochemistry. Canadian Journal of Botany, 73(3): 391-412

de Torok, D. 1968 The cytologic and growth characteristics of tumor and normal clones of Picea glauca. Cancer research, 28(3): 608-614

Dodueva, I. E., N. V. Frolova and L. A. Lutova 2007 Plant tumorigenesis: different ways for shifting systemic control of plant cell division and differentiation. Transgenic Plant Journal, 1(1): $17-38$

Eklund, L. and H. Säll 2000 The influence of wind on spiral grain formation in conifer trees. Trees, 14(6): 324-328

Eom, Y. G. and Y. J. Chung 1994 Tumor wood anatomy in Korean red pine (Pinus densiflora). IAWA Journal, 15(2): 149-155

Filipescu, C. N., E. C. Lowell, R. Koppenaal and A. K. Mitchell 2013 Modeling regional and climatic variation of wood density and ring width in intensively managed Douglas-fir. Canadian Journal of Forest Research, 44(3): 220-229

Gülsoy, S. K., H. Eroğlu and N. Merev 2005 Chemical and wood anatomical properties of tumorous wood in a Turkish white oak (Quercus robur subsp. robur). IAWA Journal, 26(4): 469476

Hajdas, I. 2009 Applications of radiocarbon dating method. Radiocarbon. 51(1): 79-90

Huang, W. C., M. C. Jane, N. Fujimoto, H. C. Lin 2020 Micropattern of Taiwan cypress burl wood figures. Journal of the Faculty of Agriculture Kyushu University. Japan, (In publishing)

Kelly, S. M. and L. M. Black 1949 The origin, development and cell structure of a virus tumor in plants. American Journal of Botany, 36(1): 65-73

Kilic, A., S. K. Gülsoy, E. Windeisen, H. Jeske and G. Wegener 2012 Characterizing of abnormal formation in hardwood. European Journal of Wood and Wood Products, 70: 373-375

Kirz, J. and C. Jacobsen 1995 Soft X-ray microscopes and their biological applications. Quarterly Reviews of Biophysics, 28(1): $33-130$

Kuzmin, Y. V. 2009 Radiocarbon and the old world archaeology: Shaping a chronological framework. Radiocarbon, 51(1): 149172

Lin, H. C., T. Ohuchi, Y. Murase and T. C. Shiah 2005 Manufacturing flame-retardant panels from Japanese cedar by the pressure process combined with hot pressing techniques. Journal of the Faculty of Agriculture Kyushu University. Japan, 
50(2): 327-341

Littau, V. C. and L. M. Black 1952a Spherical inclusions in plant tumors caused by a virus. American Journal of Botany, 39(1): 87-95

Littau, V. C. and L. M. Black 1952b Spontaneous tumors in sweet clover. American Journal of Botany, 39(3): 191-194

Lukmandaru, G. 2015 Chemical Characteristics of Teak Wood Attacked by Neotermes tectonae. BioResource, 10(2): 20942102

Roque, R. M. and M. Tomazello Filho 2007 Relationships between anatomical features and intra-ring wood density profiles in Gmelina arborea applying X-ray densitometry. Cerne, 13(4): 384-392

Schweingruber, F. H 2007 Wood structure and environment.
Springer Science \& Business Media, America. pp. 1-279

Westing, A. H 1965 Formation and function of compression wood in gymnosperms. Botanical Review, 31: 381-480

White, P. R. and W. F. Millington 1954a The distribution and possible importance of a woody tumor on trees of the white spruce, Picea glauca. Cancer Research, 14(2): 128-134

White, P. R. and W. F. Millington 1954b The structure and development of a woody tumor affecting Picea glauca. American Journal of Botany, 41(4): 353-361

Wood, R. 2015 From revolution to convention: the past, present and future of radiocarbon dating. Journal of Archaeological Science, 56: $61-72$

Wikipedia 2020 the free encyclopedia, 10202020 https://en.wikipedia.org/wiki/Burl 